\title{
A DUBUQUE COUNTY IMMIGRANT FROM THE GRAND DUTCHY OF LUXEMBURG
}

\section{By Elizabeti Nennig}

Peter John Nennig is a well known pioneer and former trader. During the eighty-seven years of his life he has crossed the Atlantic Ocean five times, attended the World's Fair in Chicago, met Father De Smet, S. J., apostle of the Flathead Indians, in Europe, and visited with members of the deputation who accompanied the missionary from St. Louis to Montana a half century ago.

Uncle Peter is an interesting story teller, despite his eightyseven years. But to get him to talk you must let him tell it in the Luxemburg language, "the only one good for stories," he claims. However, if you discuss business affairs, he is all English. His prayerbook is German, and if he talks to Dad about things he wishes to keep private he uses French.

When I asked him one day what he wanted me to remember most, he said: "Stick to your religion whatever your tribulations. Never omit your daily prayers no matter what difficulties you have. Everybody has his share of trouble and no one escapes a certain amount. And don't let yourself be persuaded against your better judgment. Nor let yourself be unduly influenced by others. Too many good people have lost their life's savings by trusting glib tongued swindlers and promoters of this and that."

This born philosopher was quite active in his days. He was a trader, a dealer in poultry. With his team he made the rounds of the farms in Key West, IaMotte, Garryowen and Bernard, and, of course, the Dubuque market. He was employed on Mississippi steamers; was a baker for four years; farmed in Dubuque County, in South Dakota and in Canada; drove a team of horses to the Black Hills, South Dakota; attended the World's Fair in Chicago; was with the Flatheads on the Indian Reservation in Montana, and made a trip to Florida. He told me he went as far south as the railroad would take him, to Fort Meyer, Florida, and as far north as the railroad went, to Prince Albert, Saskatchewan, Canada.

That is not all. In the last fifty-seven years he crossed the 
Atlantic Ocean five times, in 1873, 1876, 1878, and twice in 1892. His curiosity ever urged him on to visit new places and see new things, "a bad habit," he said with a twinkle in his eyes, referring to the proverbial rolling stone that gathers no moss.

$\mathrm{He}$ is a great reader and remembers history. What $\mathrm{I}$ write as his amanuensis, is only part of what he told me. Permit me to place the narrative in the first person. Now Uncle Peter is speaking:

I was born on the Buchholz farm near Syren, a village in Luxemburg, Europe, on January 1, 1845, and was baptised Peter John. That was the year before Iowa became a state. My father was Nicholas Nennig, and my mother was Mary Catherine Sadler of Duedelange, Luxemburg. Father was born across the frontier in 1770 and worked on French farms in the days when Robespierre was feeding nobility and priests to the guillotine, turning France topsy turvy. Seldom did he see a priest and then only in disguise, he told me. Finally father married and settled in Wies, across the Luxemburg border. He became an innkeeper. During the wars of 1810-15, when the armies of Napoleon traversed the country, he was mayor of Mondorf, today a city well patronized on account of its medicinal springs. Father was kept busy making accommodations for the soldiery, but he got along well because he spoke both French and German.

One of these soldiers who passed through Mondorf on his way to Russia was Mr. Poiret of Oetrange who later became the father-in-law of one of my brothers. This Poiret was one of an army of 400,000 who marched to Russia to return defeated and discouraged, just 40,000 strong. What an ending! Poiret's saddle pistols, dated 1810, served in the bloody task to cover the retreat over the Beresina, a Russian river. They remained in the Poiret-Lorang family, and were brought to Dubuque in 1922, when my nephew visited in Luxemburg.

In 1820 father bought the Buchholz farm, which formed part of the property of the Abbey of St. Maximin at Treves, in ancient days. Father had ten children and died at the age of cighty-two. In his younger days he kept school in his home, teaching older boys French. He was a lover of trees, planted the hills of the farm with firs, evergreens, and in his old days was proud of his mighty forest. The Buchholz farm is also known for its variety of splendid cherry trees, fifty feet and higher. [I saw these trees with my own eycs in 1920 when I was over there.-E. N.]

My first job was sheepherding. We had a hundred head. I preferred this work to books, but my younger brother was a regular bookworm. He died in his young days, a professor of languages at the University of Liege, Belgium.

From 1867 to 1873 I was custodian at the seminary in Luxemburg. Among other important people I had the good fortune to meet Father 
Peter De Smet, S. J., who lectured on the Flathead and Sioux Indians in America; also Father Kauder, a native of Luxemburg, who had been a missionary among the Montana Indians.

Why did I come to America? Why did so many people of the grand duchy come to the United States? It was not because of religious troubles, nor was it on account of wars. We emigrated bccause of economic conditions, which were decidedly unfavorable in Luxemburg in those days.

The years after the German-Franco War ushered in an era of overproduction and were followed by years of deflation, bank failures, bad crops, and general unemployment. For these reasons close to 8,000 people emigrated from Luxemburg to the United States from 1870 to 1880. And from 1830 to 1870 some 15,000 had found a new home in this country. They wrote to their kin in the old country, praising land and people in the states of New York, Ohio, Kansas, Illinois, Wisconsin, Minnesota, but especially Iowa. News from Iowa appeared in our newspapers. One of these journals carried a splendid account of the dedication of St. Mary's Church, Dubuque, in February, 1867. Twenty-ninc years before, in 1838, Mr. J. B. Noel had been the first emigrant from Luxemburg to cross the Mississippi and settle in Jackson County. 'That county in 1885 numbered 275 families from my country, and Dubuque County 450 families. More than 30,000 of my countrymen had settled in the Middle West before 1888. They brought with them close to $\$ 6,000,000$ and owned 545,000 acres of land. More than 1,000 fought in the Civil War.

I suppose that is enough explanation why I emigrated to the United States in 1873. The "Nevada" was a combination sail and steamboat. I came at the wrong time. Hard times had hit this country. General Grant had just been inaugurated again. Baltimore was visited by a conflagration that burned over ten acres of ground. New York had a financial panic. In 1874. the reds made a communistic demonstration. In the same year another conflagration in Chicago destroved over 1,000 buildings. There was no market for farm products and consequently little work in the cities. My trade (I was a baker) was at a standstill. I recrossed the Atlantic in 1876 and worked as a baker, "garcon," in Metz. We worked day and night, providing the garrison with bread and buns. For two years I stuck it out and returned to America late in 1878. That winter I worked in a paint factory in St. Louis, also in a slaughterhouse, and later on Mississippi steamers, loading and unloading freight. Many of the deck hands lost their meager earnings to thieves who plied their trade when we slept.

Shortly after South Dakota opened to settlers I went there. For six years I farmed in Jerauld County. Dakota was then still a territory. I applied for and received my second citizenship paper in 1886, and swore off allegiance to a ruler whose subject I had never been. Luxemburg is an independent grand duchy. Perhaps a few words of history will explain things. 
Long before the Roman conquest the country of Luxemburg was inhabited by Celts, a branch of the Trevirs. The Romans conquered the country in 53, B. C., and by way of fortified camps held it, calling it Ardenna, till 496 when it became a part of the empire of Charles the Great. The ruins of one of these camps are near the Buchholz farm. Christianity was preached in Luxemburg by St. Willibrord, apostle and bishop of the Friesians. He came from Ireland and is buried in his abbey-church, which later became a basilica, in Echternach, Luxemburg. His burial place is visited by thousands of pilgrims on Tuesday after Pentecost Sunday.

From 963 to 124.7 the country was ruled by native counts and by those of Limburg. One of these was also King of Bohemia, called John the Blind, who died a hero's death in the battle of Crecy, when the English defeated the French.

It was in those days when the abbot of the abbey at Luxemburg city opened the first schools. From 1443 till 1506 Luxemburg was ruled by the house of Burgundy. From 1506 to 1714 it was under Spanish rule. In the Peace of the Pyrenees in 1659 the first dismembering of Luxemburg occurred. The southern part of the country was annexed by France.

From 1714 to 1795 the fortress and country of Luxemburg were under Austrian rule. In that year the fortress succumbed to the siege of the French. They enlarged the fortifications and made this stronghold the "Gibraltar of the North." The French rule lasted till 1814. With the defeat of Napoleon at Leipzig and the entry of the allies in Paris, the fortress of Luxemburg was forced to surrender, after having driven off the attacking Hessians. Luxemiourg was subjected to a second dismembering. Germany annexed all of the Luxemburg territory on the east side of the Moselle, Sauer and Our rivers, with some 50,000 population.

For a time Luxemburg was under Holland rule; together with Belgium the three countries were known as the Netherlands. Belgium, by revolution, won its independence in 1831, and seized the western part of Luxemburg, which is twice the size of the present grand duchy. Thus Luxemburg was dismembered for the third time by its "friends."

In 1867 the powers convened in London, ordered the fortress which had been under a German military governor since 1815, dismantled and solemnly guaranteed the country's independence. Since then the country has had its own rulers. Before the World War Luxemburg was a member of the German customs union; after the war it entered a customs union with Belgium. It is too small a country to assume the expense of collecting customs at its borders. It has an area of 639,000 acres. [Dubuque County numbers 391,000 acres.-E. N.]

Luxemburg was not able to have its own consuls in the United States till quite recently. This delay may be the reason for the ridiculous legend in the papers "Luxemburg, German." Luxemburg had many foreign rulers since the days of the Romans, but its independence since 1867 entitles it to the designation, Luxemburg, Europe, no more, no 
less. County officials, census officers and newspaper editors ought to know that much.

Hard times, deflation and the lone bachelor life forced me to give up farming in South Dakota and I returned to Dubuque County in 1887. Four years later I drove by team to the Black Hills, South Ditkota. This forest of evergreens is visible at a distance of seventy miles.

During the summer of 1892 I made another trip to the old country and in the following year attended the World's Fair in Chicago. I was more than anxious to see the Chicago fair, because I had missed the Philadelphia Exposition in 1876, the year when I returned to Europe for the first time. Luxemburg firms were well represented at the Chicago fair, where the display of rose cultures from Limpertsberg captured first prizes.

In 1893 I was in Saskatchewan, Canadi. While there I had the pleasure to see a young friend from Dubuque, who is today a well known priest, professor, and historian. Several years later I drove to the Flathead Indian reservation in Montana. I met members of the deputation who had gone to St. L.ouis half a century before to beg for the services of Father Peter De Smet, S. J. I could not talk with them because they spoke only the Sioux language.

Having been in Florida in 1914. I can truthfully claim that I taversed the country as far north and as far south as the railroads would take me.

I always returned to Dubuque County no matter what other places I visited. Nowhere else have I found a better place to live and no better people to do business with. For thirty-five years I made my home at the N. Loes farm in Key West when I was not on the road attending to trade. My route included Key West, LaMotte, Garryowen, Bernard, and of course the Dubuque market. On Saturdays I was aided by a number of boys. 'Two of them became priests, two physicians, three morticians, one an efficiency expert and one a postal inspector.

The writer asked Uncle how old the name Nennig might be. He said, it was a peculiar name and seldom seen in the States. He had not been able to trace it further than five generations. In the Middle Ages when names were Latinized his name read Nennius. A writer by that name lived in England in the ninth century and compiled a "Historia Britonum," legendary stories of the arrival of the Angles and Saxons on English soil.

Another Nennius, a high Roman official in the second century, built a summer villa on the Moselle, a few miles from Treves, the "Northern Rome." The settlement in later centuries became the town of Nennig, well known today for its wonderful Roman mosaic floor, which Uncle urges those who visit Europe not to overlook. 
Copyright of Annals of Iowa is the property of State of Iowa, by \& through the State Historical Society of Iowa and its content may not be copied or emailed to multiple sites or posted to a listserv without the copyright holder's express written permission. However, users may print, download, or email articles for individual use. 